\title{
THE DEVELOPMENT OF A COMPLEX SUPRAGLAGIAL MORAINE AT THE MARGIN OF SØRBREEN, NY FRIESLAND, VESTSPITSBERGEN
}

\author{
By G. S. Boulton \\ (Department of Geology, University of Birmingham, Birmingham, England)
} Abstract. A series of concentric debris bands crop out on the frontal stagnant zone of Sørbreen, Ny
Friesland, Vestspitsbergen. The contained debris, which is dominantly sand and silt with some clay and
gravel, is well sorted and banded, and it is thought to be derived from subglacial fluvial deposits. These
debris bands give rise to a complex series of bedded moraine ridges, and bedded and unbedded sediment
sheets on the glacier surface.

The development of a supraglacial hummocky moraine is traced and it is composed of several elements: supraglacial ridges, kettle-holes, and flowed sediment sheets, which are derived from debris bands; supraglacial fluvial deposits and clay-silt ablation tills; and englacial fluvial deposits. It is also suggested that large areas of the outwash plain are underlain by dead glacier ice.

From the present work there are several possible implications for the interpretation of Pleistocene deposits:

i. Certain types of "controlled disintegration features" may have formed supraglacially from debris bands. Some bedded features hitherto interpreted as fluvioglacial in origin may be supraglacial moraines.

ii. Certain types of "kame-and-kettle" moraine may be mainly supraglacial in origin.

iii. Complex sequences of tills and bedded sediments may have been formed during a single glacier retreat phase rather than by multiple advance and retreat.

RÉsumé. Développement d'une moraine complexe supra-glaciaire au bord du Sorbreen, Ny Friesland, Vestspitsbergen. Une série de bandes concentriques chargées de débris morainiques sortent de la zone frontale stagnante du Sorbreen, Ny Friesland, Vestspitsbergen. Les débris, où dominent sable et vase avec quelque peu de gravier et d'argile, sont bien triés et laminés, et l'on pense qu'ils proviennent d'un dépôt fluviatil sous-glaciaire. Ces bandes de débris donnent naissance à des séries complexes de talus morainiques lités, et à des couches de sédiments lités ou non à la surface du glacier.

Le développement d'une moraine hommockée supra-glaciaire est tracée et il est composé de plusieurs éléments: talus supra-glaciaires, trous de dolines, et couches de sédiments coulés, qui dérivent des bandes de débris; dépôts fluviatils supra-glaciaires et dépôts d'ablation de vase et d'argile; et dépôts fluviatils intraglaciaires. Il est ainsi suggéré que de larges surfaces de la plaine d'évacuation sont pavées de glace de glacier mort.

Du présent travail, plusieurs possibles implications existent pour interprèter les dépôts pleistocènes:

i. Certains types de formes de desintégration contrôlée ont pu se former à la surface de la glace à partir des bandes de débris. Quelques formes lités jusqu'à présent interprètées comme d'origine fluvioglaciaire peuvent être des moraines supra-glaciaires.

ii. Certains types de kame et kettle moraine ont pu avoir une origine principalement supra-glaciaire.

iii. Des séquences complexes de dépôts et de sédiments lités ont pu être formées pendant une phase d'un seul retrait de glacier plutôt que par des avances et retraits multiples.

Zusammenfassung. Die Bildung einer komplexen Moräne auf dem Eis am Rande des Sorbreen, Ny Friesland. Vestspitsbergen. Eine Serie konzentrischer Schuttbänder taucht in der stagnierenden Frontzone am Sorbreen, Ny Friesland, Vestspitsbergen, auf. Der darin enthaltene Schutt, der hauptsächlich aus Sand und Schlamm mit etwas Ton und Schotter besteht, ist wohlsortiert und gebändert. Es wird angenommen, dass er von subglazialen Flussablagerungen stammt. Diese Schuttbänder lassen eine komplexe Serie von geschichteten Moränenrücken sowie von geschichteten und ungeschichteten Sedimentdecken auf der Gletscheroberfläche entstehen.

Die Bildung einer buckligen Moräne auf dem Eis wird verfolgt. Sie besteht aus verschiedenen Elementen: Rücken, kesselartigen Löchern und überflossenen Sedimentdecken, die von Schuttbändern herrühren; fluviatilen Ablagerungen auf dem Eis und Ablationsbänken aus Ton-Schlamm; schliesslich fluviatilen Ablagerungen im Eis. Es wird angenommen, dass unter weiten Bereichen der Aufschüttungsebene noch Toteis liegt.

Aus den vorliegenden Untersuchungen lassen sich einige Folgerungen für die Deutung pleistozäner Ablagerungen ziehen:

1) Gewisse Typen von "controlled disintegration features" können aus Schuttbändern an der Gletscheroberfläche entstanden sein. Einige geschichtete Erscheinungen, deren Ursprung bisher als fluvioglazial angesehen wurde, können Moränen auf dem Eis sein.

2) Gewisse Typen von "Kamm und Kessel"-Moränen können hauptsächlich auf dem Eis entstanden sein.

3) Komplexe Folgen von gebankten und geschichteten Ablagerungen können sich während einer einzigen Gletscherrückzugsphase gebildet haben anstelle eines mehrfachen Vorstosses und Rückzuges. 


\section{INTRODUCTION}

Sørbreen, one of several westerly outflows of the Ny Friesland ice cap, lies on the eastern side of Widjefjorden, northern Vestspitsbergen, at lat. $79^{\circ} 30^{\prime}$ N., long. I $6^{\circ}$ E. (Fig. Ia). It has a width of $\mathrm{I} \cdot 5^{-2} \cdot 0 \mathrm{~km}$., an average surface gradient of $\mathrm{I}$ in $\mathrm{I} 4$ and flows down to the fjord in a westerly direction between steep rock walls. The rocks over which the glacier flows are dominantly Hecla Hoek quartzites and sandstones, which provide abundant well-sorted and easily eroded sediments. The glacier front is bi-lobate in form; there is a large area of gently dipping, stagnant ice at the margin of the northern lobe, and another small area of stagnant ice in the northern part of the southern lobe (Fig. Ib). These stagnant zones are bounded on their up-glacier sides by a steep wall formed by the active ice to the east.

In the early part of August 1965, a detailed study was made of a series of supraglacial ice-cored ridges and mounds together with the associated sediments, which occur on the stagnant frontal zones of the glacier (Fig. Ic). Many of these features are composed of bedded sand and gravel, and at first sight many appeared to be fine examples of eskers, kames and other fluvioglacial forms. But on detailed examination it became clear that most of these features had developed entirely subaerially after sediment had been deposited on the glacier surface from a series of englacial debris bands ([Ward], I953). These features are therefore moraine ridges, which have a similar origin to the "shear moraines" described by Bishop (1957) and Swinzow (1962) from Greenland. Some bedded ridges gave no definite indication whether they were moraines or of fluvioglacial origin but they were so similar to ridges demonstrably derived from debris bands that a fluvioglacial origin seemed unlikely.

Fine-grained debris derived from these bands also gives rise to an extensive, flat-lying supraglacial moraine consisting of complex sequences of bedded and unbedded sediments similar to those observed in areas of Pleistocene glaciation. A large number of englacial stream channels, some of which are filled by fluvial sediments, occur within the stagnant frontal zones of the glacier. Two such infilled channels have given rise to eskers which now crop out supraglacially, one of them passing into an ice-cored fan at its lower end where it is surrounded by moraine ridges.

Much of the debris load of the glacier is concentrated in bands in the basal part of the ice. In the stagnant zone of the northern lobe the majority of these debris bands dip up-glacier at angles greater than $70^{\circ}$, but in the southern part of this stagnant zone (south of A in Figure Ic) and in the small stagnant zone of the southern lobe similar debris bands have dips between $30^{\circ}$ and $70^{\circ}$, whilst those which crop out in the steep active ice front to the south have an even shallower $\operatorname{dip}\left(<30^{\circ}\right)$.

\section{Distribution and Nature of the Englacial Debris}

Debris is carried within the glacier in two structural positions:

i. Disseminated throughout the ice in the basal part of the glacier. This debris is completely unsorted and ranges from clay to boulders $2.4 \mathrm{~m}$. in diameter. The concentration of this debris in the ice rarely exceeds 15 per cent (by volume) and it is generally less than 7 per cent.

ii. Debris is carried in bands, which are up to $\mathrm{I} \mathrm{m}$. thick. The debris, which is tightly packed and frozen, consists mainly of sand with a little gravel or silt, or silt with a little clay. Pebbles and sand grains contained within these bands are generally well rounded, suggesting that they have previously undergone fluvial transport. The debris is sometimes layered, some of the thinner, sandy debris bands showing an interesting tripartite layering, a fine-grained middle layer grading into flanking coarser-grained layers. Many of the clayey-silt bands are unlayered or have a layering too fine to be detectable. The thicker debris bands often exhibit complex interdigitations of sand, silt, 


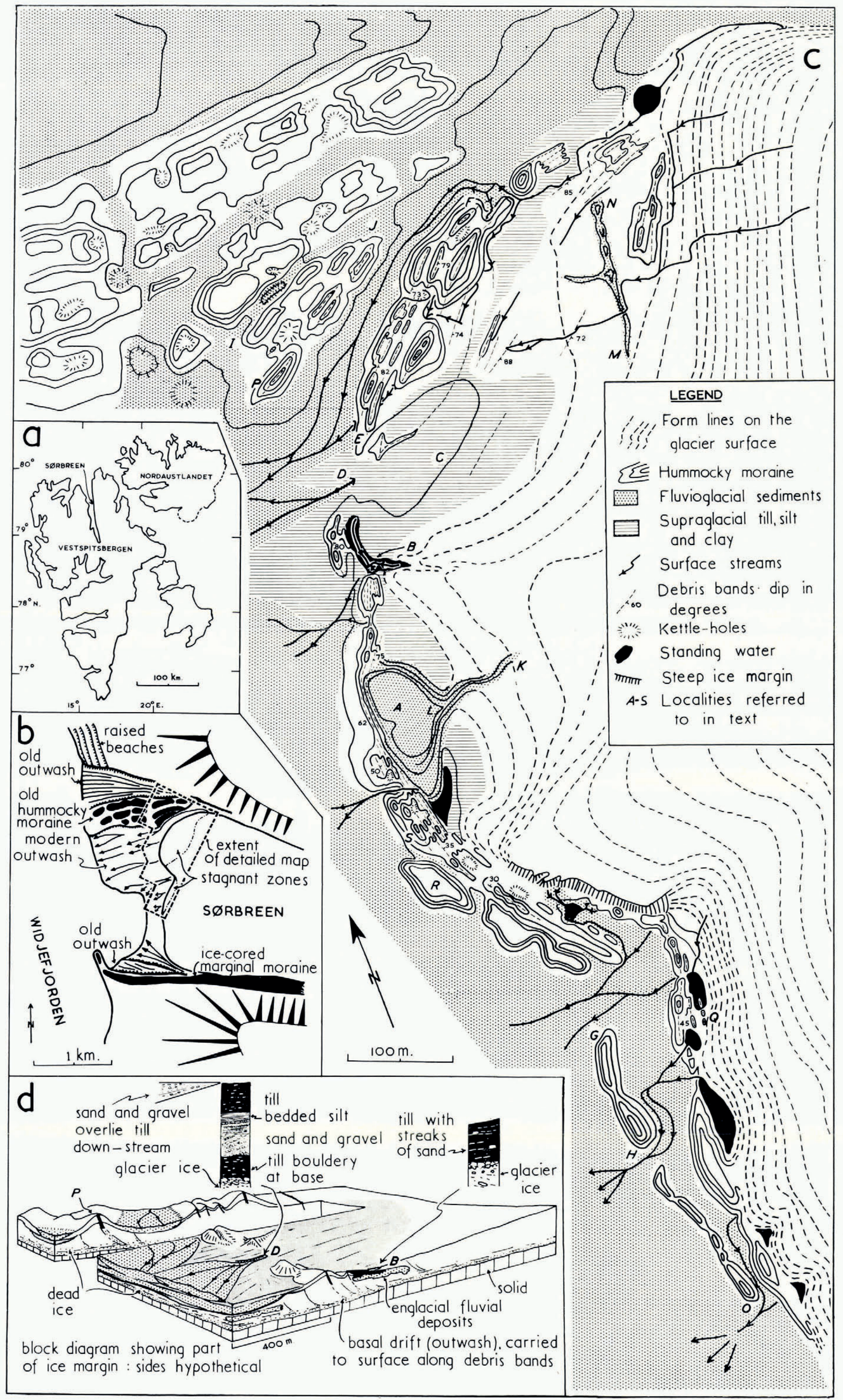

Fig. I. a. General map of Vestspitsbergen and adjacent islands

b. Map showing the position of Serbreen on the eastern side of Widjefjorden. This map was prepared by D. Masson-

Smith (Harland and Masson-Smith, 1962 )

c. Map of part of the snout of Sorbreen

d. Block diagram showing part of the margin of Sorbreen 

clay and gravel, this included material sometimes being highly contorted although the bounding ice walls are plane surfaces (Fig. 2).

The debris : ice ratio within a debris band appears to vary with the grain-size of the debris. When this consists of sand and gravel, there is no apparent diminution in volume on thawing of the interstitial ice, suggesting that only the pore spaces between the tightly packed particles are filled with ice. When silt or clay is entrained within a debris band, its volume may be reduced on thawing to as much as 90 per cent of the original in the case of a silt-rich sample, and as little as 35 per cent in the case of a clay-rich sample. Thus it is likely that some of the lamination seen in frozen clay and silt debris bands will be disturbed by contraction when the ice melts. Thin ice lenses, in contrast to interstitial ice, are sometimes contained within debris bands. They show a fine banding due to the alternation of layers of ice crystals with an average diameter of $5 \mathrm{~mm}$. and layers of crystals with an average diameter of $\mathrm{I} \mathrm{mm}$.

At locality Q (Fig. Ic), medium-angle $\left(30-60^{\circ}\right)$ debris bands crop out in the stagnant ice, whilst a few metres to the east, on the steep active ice cliff, low-angle $\left(<30^{\circ}\right)$ bands crop out. The bands exposed at this locality illustrate the way in which the grain-size of debris varies from band to band. The following debris types were observed from west to east in successive bands: sand, silt and clay, sand and silt, silt

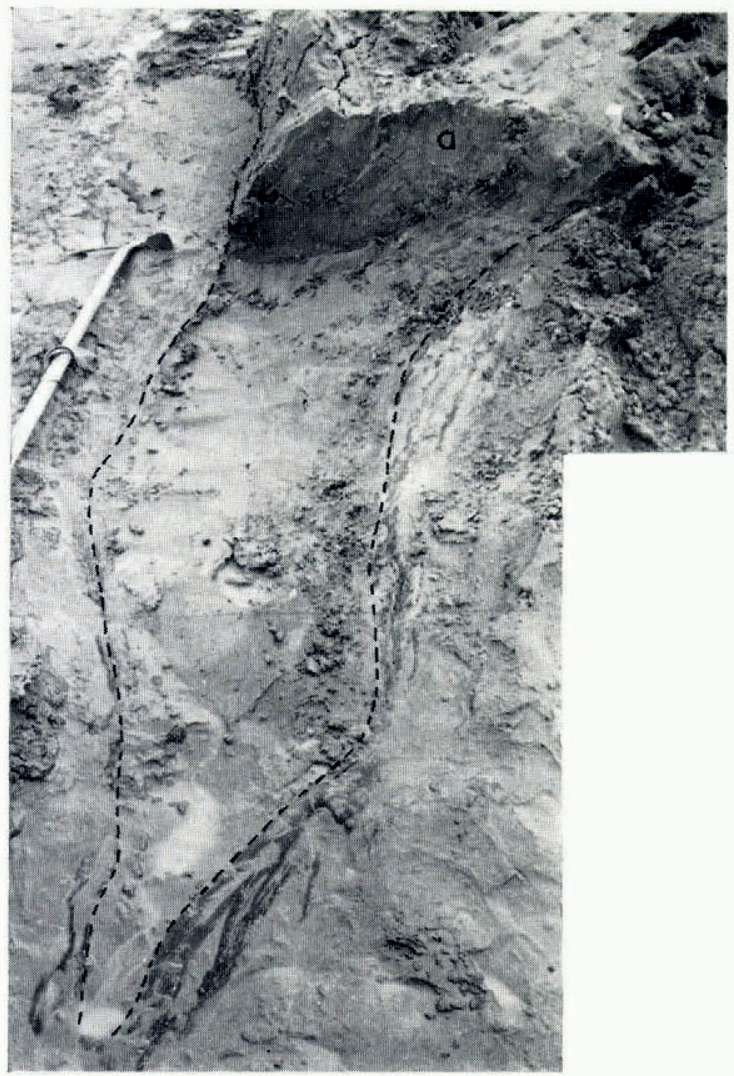

Fig. 2. A ridge excavated to show part of the lenticular outcrop of a medium-angle debris band on the glacier surface. The debris/ ice contact is shown by a pecked line. Note the banding in the vertical face " $a$ ". A section through part of this ridge is shown in Figure $10 b$ 
and clay, sand and gravel. The grain-size of debris contained within a single band may also vary, changing from clayey silt to gravel along its strike.

Debris is also irregularly distributed along the strike of these bands; there may be no debris at one point and up to $0.9 \mathrm{~m}$. in another (Fig. 2). However, vertical sections through debris bands do not show any variation in thickness and thus the bands seem to take the form of rods with their axes down dip, parallel to the direction of ice movement; a similar phenomenon has been noted in Greenland by Bishop (1957) and in Antarctica by Souchez (1966).

\section{Origin of the Debris Bands}

There are several possible ways in which the debris bands could have originated:

i. They could be relict crevasses into which sorted and bedded fluvial sediments have fallen, subsequent compression having given them their present form.

ii. They could represent beds which were deposited in the accumulation area and have subsequently reached the glacier surface in the ablation area.

iii. The material of the bands could be subglacial debris which has been frozen on to the base of the glacier by a mechanism similar to that suggested by Weertman (I96r) and brought to the surface as the flow lines turn upwards at the frontal margin.

iv. The material of the bands could represent subglacial debris which has been brought to the surface along shear planes, a mechanism suggested for similar debris bands in the Thule area of Greenland (Bishop, I957).

Alternative (i) is unlikely because it cannot explain the layering parallel to the containing walls of the debris band, and because it would require a pattern of deposition which would fill one crevasse with sorted silt and clay, and flanking crevasses with sorted sand and gravel, an extremely unlikely occurrence.

Explanation (ii) can be eliminated as there is no suitable basin of sedimentation in the accumulation area, and the many debris bands which have a graded coarse-fine-coarse layering suggest that such an origin is unlikely. (Upward grading from fine to coarse particles is not uncommon in lakes but it seems too much of a coincidence that several temporary lakes should have existed in the accumulation area which gave rise to an exactly similar graded cycle from coarse to fine to coarse.)

Alternatives (iii) and (iv) are much more acceptable. In both of these the debris would be fluvioglacial material picked up from the glacier bed and transported along planar structures to the surface. The variation in the type of sediment contained within the debris bands could then be explained as being a result of variation in the sediments on the glacier bed. There are thus two possible explanations for the layering in the debris bands. If the bands are flow lines, the layering could have resulted from freezing of subglacial sediment on to the bottom of the glacier as suggested by Weertman (I96I). Alternatively, if they are shear planes, the layering could have been produced by shearing in the manner predicted by Bagnold (1954). He showed that in the inertia region of grain flow the dispersive pressure varies as the square of the grain diameter for a given shear stress. This suggests that when grains of mixed size are sheared together, the larger grains should drift towards the zone of least shear strain and the smaller grains towards that of greatest shear strain. If this mechanism were applied to the debris bands showing the graded coarse-fine-coarse layering, it would imply that the middle of the band was the zone of greatest shear strain. Such an explanation relies on the assumption that the effects of grain inertia are dominant during shear across the debris band, as no dispersive pressure can be detected during viscous flow. The bands which have a coarse-fine-coarse layering are composed of sand and, as has been shown on p. 719, the ice contained within these bands lies in the interstices between tightly packed grains rather than separating them. It is 
therefore reasonable to assume that the effects of grain inertia would be dominant during shear across such a band.

It is possible that the debris bands cropping out on the surface of Sørbreen represent both shear planes and frozen-in debris bands of the type envisaged by Weertman (Ig6r). If this is so, the coarse-fine-coarse bands probably represent the former, whilst many of the thicker, more complex bands may represent the latter.

\section{Debris Dykes on the Glacier Surface}

As the glacier ice ablates, steeply dipping debris bands originally enclosed within the ice project above the glacier surface. Nearly vertical bands (which are frozen) tend to stand up as dykes (Fig. 3) and, as material of the dykes slowly thaws, it peels away to give the dyke a characteristic form resembling a cocks-comb. If the dykes are composed of sand and gravel, the interstitial ice melts out rapidly and the debris slumps on to the surrounding ice, building up ridges which are described on p. 723. If, however, the dykes are composed mainly of clay or silt, the interstitial ice thaws out relatively slowly and the dykes may reach a height of $\mathrm{I} \cdot 05 \mathrm{~m}$.

Debris bands that crop out as dykes on the glacier surface have been described by Koch and Wegener (1917) from Greenland, where till dykes reached a height of io m., by Woldstedt (1954) from Iceland and also from Vestspitsbergen by Gripp (1929). Those described by Gripp were composed of till or silty clay or sand and were termed Lehmmauern (clay walls) by him. He inferred that they represented debris which had risen from a subglacial position via crevasses in the ice. His reasons for this were that the Lehmmauern were vertical and had no direction of preferred orientation, an observation which he considered to rule out the shearplane origin which Lamplugh ( I I I I) suggested for these structures. He took the view that the absence of preferred orientation indicated that the crevasses had formed in stagnant ice, and that subglacial material had risen up the crevasses because of the simple load pressure of the

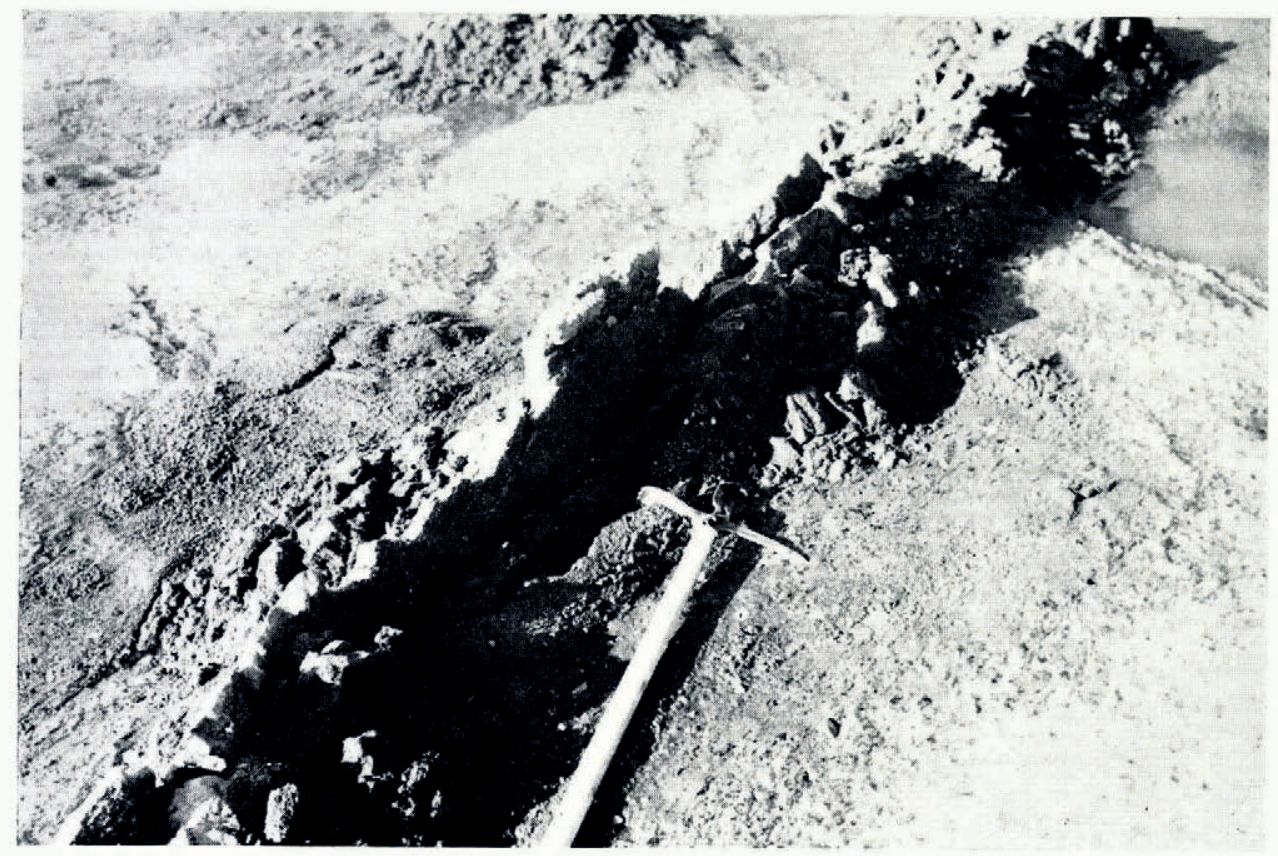

Fig. 3. High-angle band of sandy debris, cropping out as a small dyke on the glacier surface. The dyke is splitting along its banding 
ice on its substratum. An integral part of Gripp's hypothesis (as expressed by Schott (1934)) appears to be that subglacial till, soaked by melt water, forms a plastic mass which is squeezed up by the weight of the ice into basal crevasses. This hypothesis cannot however be applied to Sørbreen as much of the debris is sand and gravel and, although the clay and silt beneath the ice might be wet, it is frozen when contained within debris bands. The debris dykes on the glacier surface could not therefore have been forced up basal crevasses as a plastic mass. Indeed the process of formation envisaged by Gripp for his Lehmmauern seems unlikely as these were also frozen and he specifically states that: “. . . wir eisfreies Moränenmaterial unter dem Eise, also Grundmoräne in engerem Sinne, nirgends gesehen haben" [". . . nowhere have we seen subglacial ice-free moraine, or ground moraine sensu stricto"'].

These two observations appear to deny the conditions under which material could be forced up basal crevasses, viz. that there should be a considerable amount of subglacial till beneath a distinct ice/till contact and that the till should be a fluid plastic mass.

\section{Flat-lying Supraglacial Sediment}

Although silt and clay dykes thaw only slowly, the material which slumps from them on to the ice when they melt tends, because of its fluidity, to spread as a sheet over the glacier surface. Minor ridges may be formed but they are very unstable. Silt and clay sheets derived from layered debris dykes show good bedding, but where the debris band is not layered the resulting sheet of sediment tends to lack bedding.

Thin poorly compacted tills composed of unsorted debris, which is released from the ice as ablation proceeds, also lie on some flat areas of the stagnant zone of the glacier. On slopes greater than $5^{\circ}$ the finer (clay and silt) fraction of this till tends to flow into down-slope hollows on the glacier surface, carrying sand-size material and small pebbles with it and leaving behind an open-textured remanier of boulders, gravel, sand and some silt. The material which accumulates in the hollows is thus a silt and clay-rich till, although basally it contains those boulders and pebbles which were already lying on the ice in its new locus of deposition. At one locality (Fig. Id; B) I $\cdot 05 \mathrm{~m}$. of such till is exposed in the side of a channel cut by a supraglacial stream. The basal $15 \mathrm{~cm}$., consisting of bouldery till with an open texture, lies directly on the ice which is melting rapidly and releasing more unsorted debris. The upper $0.9 \mathrm{~m}$. consists of silt- and clay-rich till with occasional streaks of sand, the uppermost $0.3 \mathrm{~m}$. of which has partly dried out and is quite compact. The fabric of the lower bouldery till is parallel to the direction of ice movement, whilst the fabric of the overlying clay- and silt-rich till is parallel to the slope of the glacier surface.

A large hollow (Fig. Ic; C) on the stagnant area of the northern lobe of Sørbreen is filled with sediment over an area of $\mathrm{r} 8 \mathrm{o}$ by $270 \mathrm{~m}$. An auger hole in the centre of this hollow proved at least $2 \mathrm{~m}$. of sediment, and small excavations showed interdigitations of clay-silt till, and bedded clays and silts. The latter contain streaks and lenses of sand, lenses of till and occasional boulders around which the bedding appears to "flow". The clay-silt till appears to be the fine fraction of an ablation till which has flowed into the hollow, whereas the bedded clays and silts are apparently derived from fine-grained debris bands.

Fine-grained tills, silts and clays also occur as sheets beyond the margin of the northern lobe. They have flowed through gaps in the marginal moraine complex and have spread out over part of the outwash plain (Fig. Ic). At one locality (Fig. Id; D) $0.5 \mathrm{~m}$. of clay-silt till and $15 \mathrm{~cm}$. of clayey silt rest on $0.9 \mathrm{~m}$. of fan gravels which are themselves underlain by $0.5 \mathrm{~m}$. of clay-silt till. The latter is poorly compacted and bouldery at the base, which rests on the glacier surface. This section is exposed in the side of a channel cut by a stream emerging from the ice, and which is itself depositing sands and gravels down-stream on top of the above sequence. The most likely interpretation of this section is that the lower, uncompacted bouldery till is an ablation till and that the overlying deposits represent successive phases of fan 
and flow till deposition. This illustrates the action of sand and gravel fans which, continually changing their locus of deposition, overwhelm previously deposited flowed tills, silts and clays which lie between earlier fans. With increasing distance from the glacier front the sedimentary environment gradually changes from one of coarse gravel fans to braided channels with sands and silts and occasional gravels, whilst the clouded waters of the fjord opposite the glacier front indicate probable clay and silt deposition. As the glacier retreats such a succession of lithologies can be expected in a vertical sequence at one place.

Sequences such as that described above are common both at the margin of many Vestspitsbergen glaciers and also in areas of Pleistocene glaciation.

\section{Topographic Forms Derived from Debris Bands}

The debris falling from a rapidly thawing dyke of sand and gravel builds up on both sides of the dyke, forming a small ridge. The underlying ice, which is insulated from insolation by this slumped debris, ablates at a much slower rate than the surrounding ice and thus forms an ice core. When sand falls from a dyke down the flanks of such an ice-cored ridge, particle dispersion results in sorting and bedding parallel to the slope is induced, the flanking sediments being built up at the angle of rest. The ice cores of these ridges, though ablating only slowly, waste down and release the unsorted debris contained within them. This builds up on the surface of the ice core and beneath the bedded sediment derived from the debris dyke. The thickness of this unsorted till-like material will depend on its initial concentration in the ice.

When the immediately subjacent ice melts, the thin till layer is wet and fluid, and it tends to initiate slumps which produce mixing of till and overlying sand. In this way complex structures of contorted bedded sand containing wisps and bands of till are produced. If the ice core has a low concentration of unsorted debris, a few slumps may be initiated by the basal till layer but large-scale movement does not occur. If the ice core has a high concentration of unsorted debris, a thick layer of till which tends to cause considerable slumping is built up directly above the ice core. This is often great enough to bare the ice core of its sediment cover except for a thin layer which tends to accelerate rather than inhibit ablation of the ice core (Østrem, I959). The slumped sediment thus forms an annular ridge of mixed till and sand around the flanks of the ice core, which wastes at a greater rate. The eventual disappearance of this central ice core hence gives rise to a rimmed kettle-hole, which may contain small pools, and its annular sediment ridge is often breached. Figure Ic shows the positions of kettle-holes in the morainic belt on the stagnant zone of the glacier.

Perhaps the most interesting supraglacial forms that are being produced on the stagnant zone of Sørbreen are a series of arch-bedded ridges composed predominantly of sand and gravel derived from debris bands. These do not appear to have been described previously and are therefore described in detail here. Both their structure and form are related to the dip of the debris band from which they are derived, and thus they are described as derived from high-angle $\left(>70^{\circ}\right)$ bands and medium-angle $\left(30^{\circ}\right.$ to $\left.70^{\circ}\right)$ bands. Low-angle $\left(<30^{\circ}\right)$ bands are restricted to the steep active ice margin and they give rise to another type of ridge.

\section{Ridges Derived from High-Angle $\left(>70^{\circ}\right)$ Debris Bands}

Figure $4 \mathrm{a}, \mathrm{b}$ and $\mathrm{c}$ shows sections across three ridges which are typical of those developing from high-angle debris bands on the stagnant zone of Sørbreen, and which probably represent successive stages of a continuous process.

Figure 4 a shows a small ridge which has developed from a debris band that crops out on the glacier surface in the stagnant zone of the northern lobe. The surface slope of the slumped sediment is about $35^{\circ}$ (the angle of rest) and the slope of the ice core is $45^{\circ}$; thus the upper part of the ice core, mantled by less sediment than its lower part, ablates at a relatively 


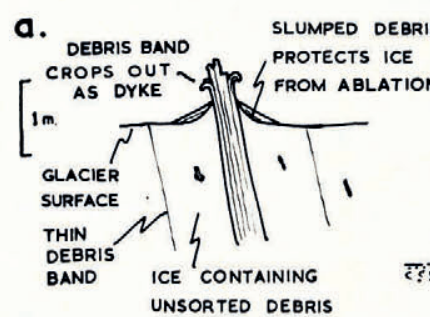

b.

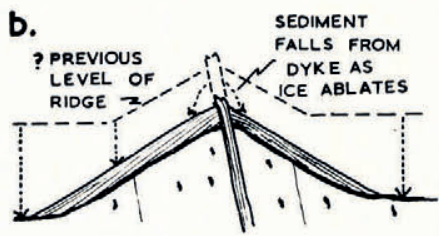

c.

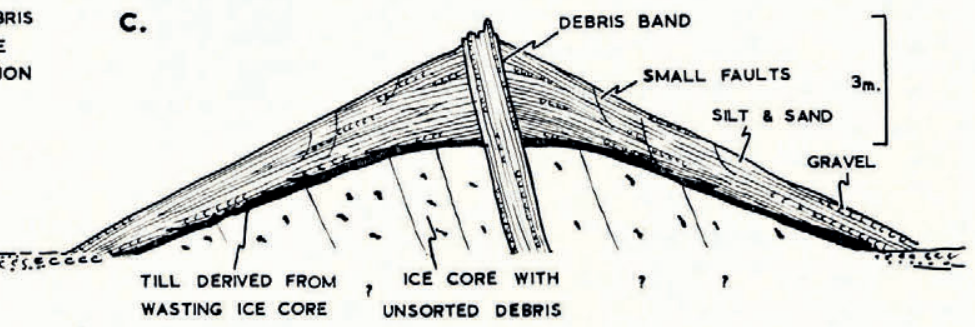

d. UNSORTED DEBRIS

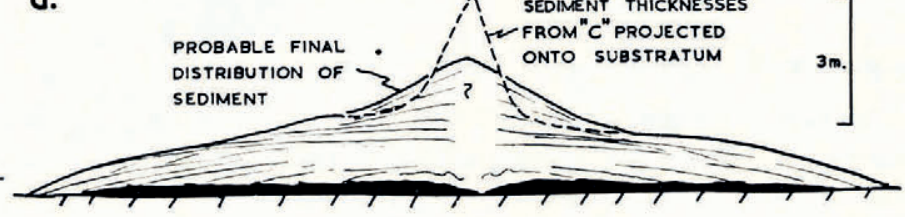

Fig. 4. $a-d$. Cross-sections illustrating the development of a ridge from a high-angle debris band. Ridges such as " $a$ " and " $b$ ", are common on the glacier surface; the ridge " $c$ " is located at P in Figure $I c$, and " $d$ " is a hypothetical reconstruction of " $c$ " with the ice core removed. Horizontal and vertical scales are the same

greater rate, resulting in reduction of the slope of the ice core. Therefore, in ridges over $0 \cdot 9^{-\mathrm{I}} \cdot 2 \mathrm{~m}$. high both the ice core and its sediment mantle slope at $35^{\circ}$ (Fig. $4 \mathrm{~b}$ ).

A rudimentary bedding parallel to the surface slope is present in ridges less than $0.9 \mathrm{~m}$. high but in larger ridges where debris travels a greater distance down the flanks a distinct planar bedding is developed parallel to the surface slope (Fig. 5). Cross-bedding is occasionally

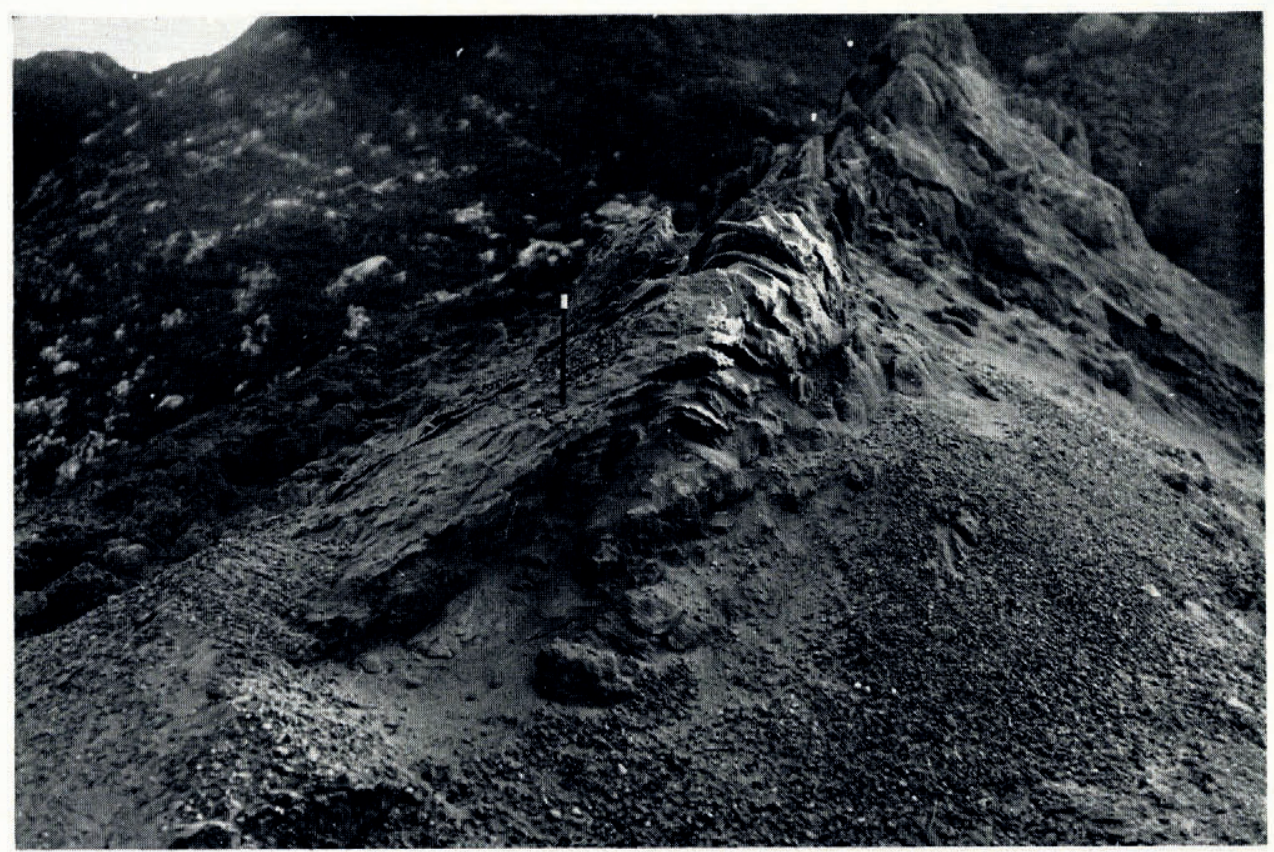

Fig. 5. Arch bedding on the crest of an ice-cored ridge derived from a high-angle debris band. Note the central debris dyke in the background. The scale is $18 \mathrm{~cm}$. long 
present and wind-induced ripples are common. Small normal faults often occur in the sediment mantle, dipping both towards and away from the crest of the ridge at angles varying from $50^{\circ}$ to $90^{\circ}$ (Fig. 6). The bedding is often dragged down along the lines of these faults, which are themselves truncated by higher bedding planes, showing that faulting was active during deposition. It is probable that some of these faults are slip planes activated by flow in the underlying till layer.

Figure 4c shows a section across an ice-cored ridge (Fig. Ic, d; P), which is typical of many which occur in the inner part of the old moraine. It appears at first to rest upon outwash sands and gravels but it is more likely that the ice core is an irregularity on a continuously buried ice surface and that the sands and gravels merely lie against the ridge (this interpretation is suggested in Figure Id). The flanks of the ice core slope at $22^{\circ}$ and it has a marked flat top on which the sediment mantle has a thickness of $2.4 \mathrm{~m}$. as opposed to $\mathrm{I} \cdot 2 \mathrm{~m}$. on the flanks. There is a gradual increase in dip from the horizontal beds directly above the flattopped ice core to those at the surface on both sides of the crest line which dip at $32-35^{\circ}$. A similar phenomenon was noted on the flanks of the ridge, where the superficial beds dip at $32-35^{\circ}$, whilst those immediately above the ice core are parallel to the surface of the core, dipping at $22^{\circ}$.

The thickness of debris contained in any one debris band varies considerably along its strike, resulting in the largest ridges being built up where the thickness of debris is greatest and vice versa (Fig. 7). For instance, E-F (Fig. Ic) is $275 \mathrm{~m}$. long and is located along the outcrop of a major debris band; it is not continuous but beaded, being broken up into six ridges of varying size by depressions where little sediment has been extruded. It is thus possible to follow the outcrop of a single debris band by tracing the ridges derived from it. Of the debris bands shown in Figure Ic, some were observed and others were inferred from ridges showing a central debris dyke along their crests.

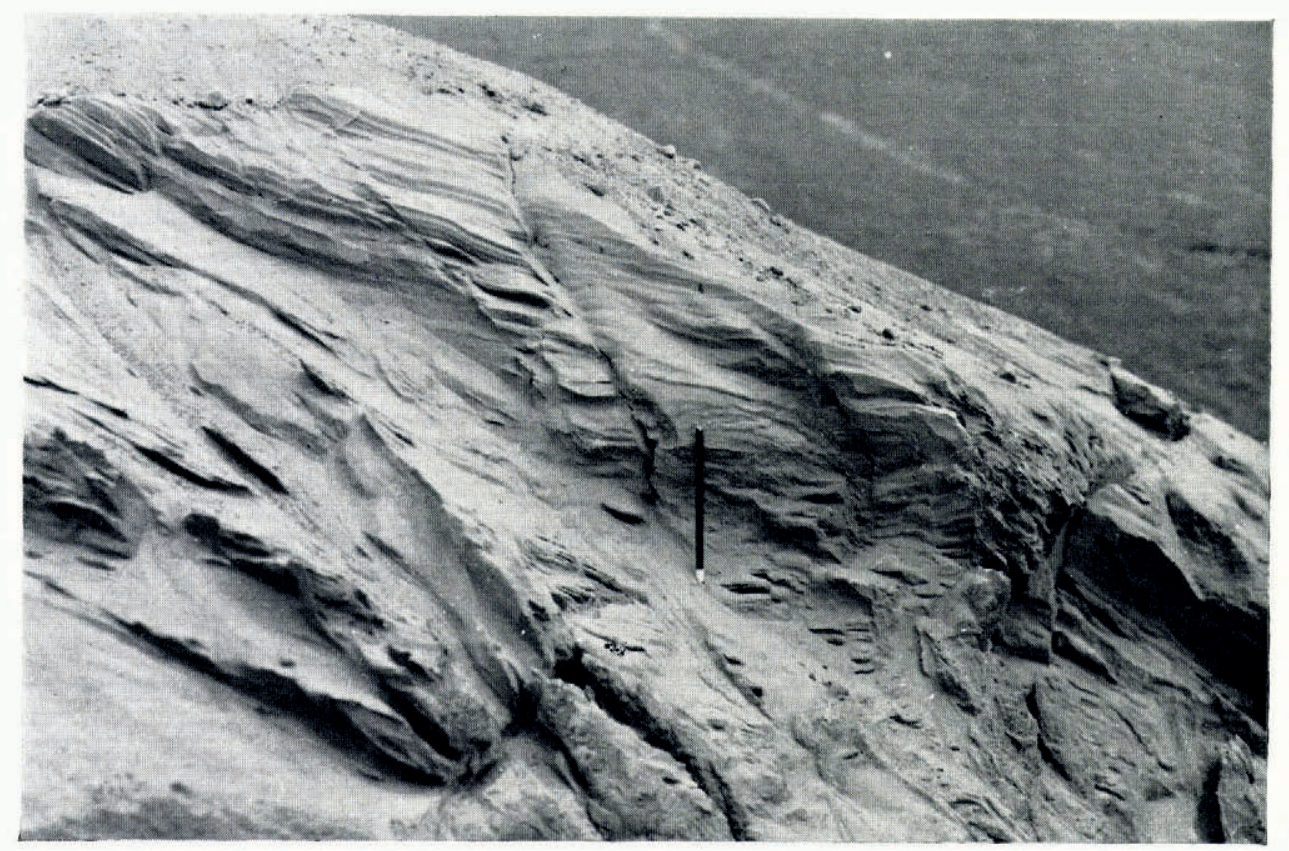

Fig. 6. Flank of an ice-cored ridge, showing planar bedding and small faults. The scale is $10 \mathrm{~cm}$. long 


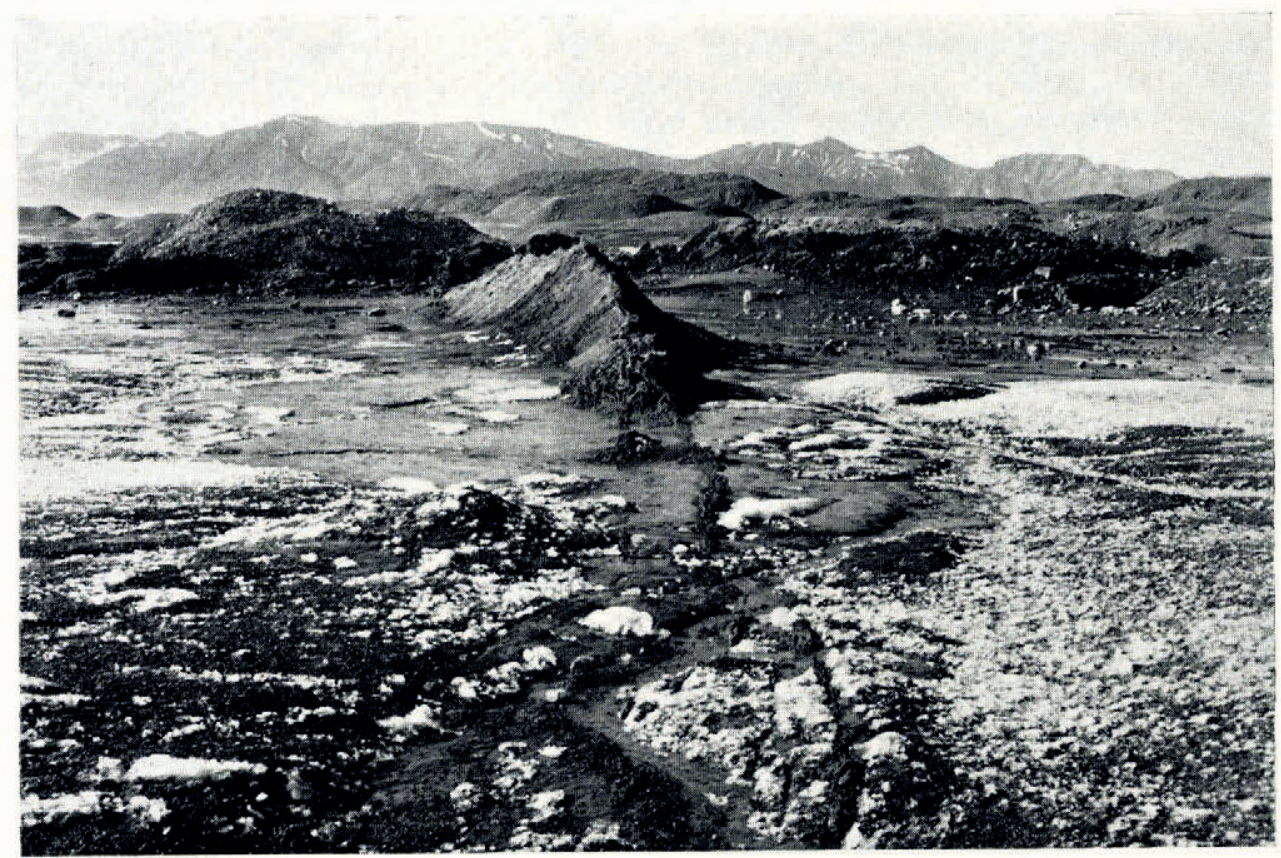

Fig. 7. An ice-cored ridge developed from a high-angle debris band. The ridge is situated along the thickest part of the band which can be traced into the foreground where it contains little debris. The height of the ridge is $3 \mathrm{~m}$. Note the old hummocky moraine in the background

The ridges shown in Figure $4 \mathrm{a}, \mathrm{b}$ and $\mathrm{c}$ are single ridges developed in relative isolation, but the majority of ridges are closely packed because of the proximity of the parent debris bands. Large ridge complexes are formed from such closely grouped debris bands, the sediments from the various bands overlapping to give complex interdigitations of bedded sands and gravel, till, silt and clay. Kettle-holes occur in these ridge complexes and supraglacial streams flow between the mounds. The channels left by these streams often have undulating long profiles due to ablation of the underlying ice. Figure 8 shows part of such a ridge complex and Figure 9 shows its down-glacier flank.

\section{Discussion}

The steeply dipping central debris band is responsible for the characteristic form and structure of the ridges described above in that it provides a continuous supply of sediment which slumps down both flanks of the ridge, where it builds up at the angle of rest. The variation of dip in the beds of the sediment mantle in those ridges in the inner part of the old moraine is related to the gradual decrease in slope of the melting ice core. Beds previously deposited at the angle of rest now dip at a lower angle because of the decrease in slope of the underlying core, whilst newly deposited beds dip at the angle of rest. These ridges therefore show a progressive decrease in dip in the bedded sediment mantle from the surface to the ice core (Fig. 4c). As the slope of the ice core decreases below $15^{-20^{\circ}}$ there is an insufficient supply of sediment from the summit to retain the beds on the flanks at the angle of rest, and so sediment builds up on the summit area alone.

In any attempt to correlate the forms described above with the products of ancient glaciation it is important to be able to infer their eventual form and structure when the ice 


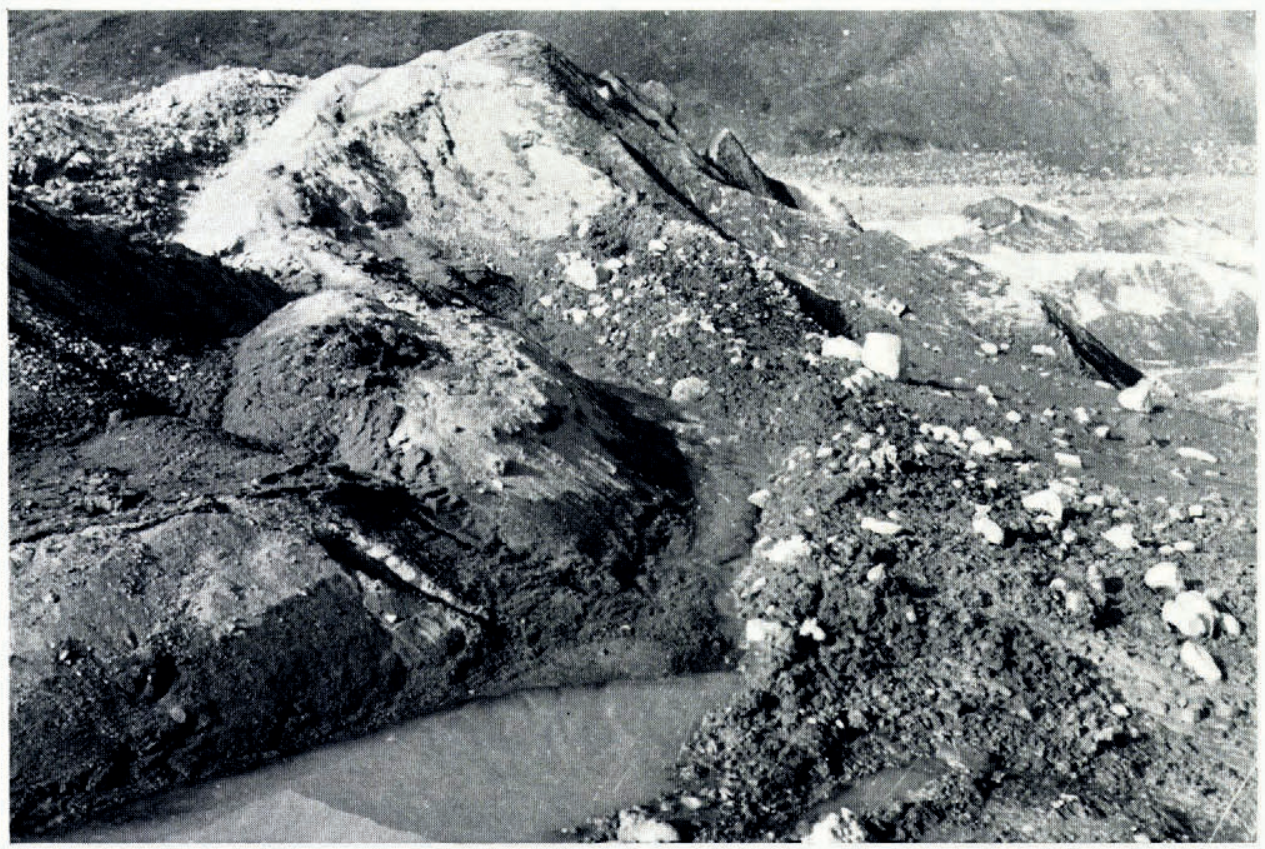

Fig. 8. Part of a ridge complex developed along the line of a series of closely packed debris bands. The highest ridge has a sand and gravel mantle, and it is cut through on the right by a stream channel. The pool in the foreground ( $5 \mathrm{~m}$. wide) lies along the line of a clayey debris band

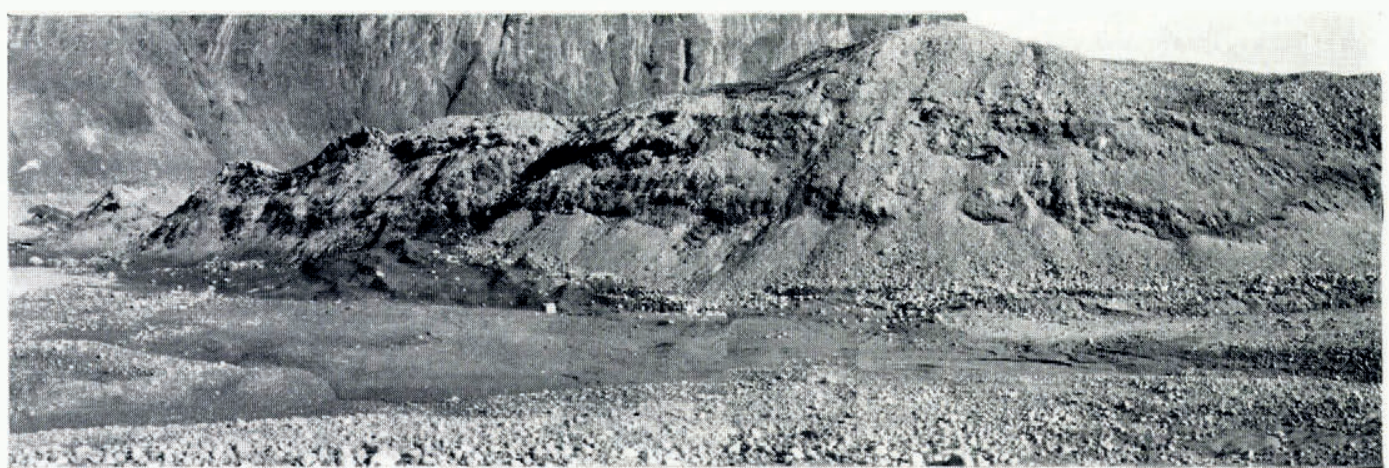

Fig. 9. Down-glacier flank of the ridge complex between $E$ and F in Figure $I c$. The ridge is $12 \mathrm{~m}$. high

cores have completely disappeared. This may be done by reference to forms which are probably of debris-band origin and whose ice cores have either completely or nearly wasted away (such forms are described on p. 730), and by attempting to predict the final forms of currently forming ice-cored ridges derived from debris bands. If it is assumed that an ice core will normally waste away without any drastic re-arrangement of the overlying sediments, the ridge shown in Figure 4c will give rise to the one shown in Figure $4 \mathrm{~d}$ when the ice core finally disappears. The sediment above the ice core has been projected down on to a horizontal plane, which could be the glacier substratum or an ice surface and, where the resultant sediment slope would have been greater than $35^{\circ}$, the sediment has been re-distributed down-slope. The 
central part of the ridge will probably retain an arch-bedded structure and some folding and faulting may result, due to re-distribution of sediment as the ice core disappears. The central debris band may well survive. The assumption that the sediment mantle will survive melting of the underlying ice may be justified by reference to ridges in the outer part of the old hummocky moraine (see p. 730) which do not appear to have ice cores and which are probably derived from debris bands.

Destruction of ice-cored ridges and other constructional forms in the immediate proglacial area of Sørbreen is caused by erosion by outwash streams rather than by mass wasting. Areas of constructional topography which have been left high above stream channels and outwash fans appear to be safe from erosion if the glacier maintains its retreat. Several Vestspitsbergen glaciers show this pattern of retreat by the presence of isolated blocks of hummocky moraine surrounded by braided outwash.

\section{Ridges Derived from Medium-angle $\left(30-70^{\circ}\right)$ Debris Bands}

In the southern part of the stagnant area of the northern lobe and in the small stagnant area of the southern lobe of Sørbreen, the debris bands are of the same thickness and structure as those farther north, but they dip up-glacier at angles of $30^{\circ}$ to $70^{\circ}$. Kettle-holes, and silt and clay sheets, are formed from these debris bands in the same way as from high-angle bands, but ice-cored ridges derived from them show a very different structure. Figure roa, b and $c$ shows cross-sections through three sand ridges which probably represent successive stages of development.

Because of the lower angle of dip of the debris band, sediment falls preferentially on to its down-glacier side, initiating an ice core on that side of, and beneath, the debris band (Fig. I oa). A further stage is shown in Figures rob and I 1 . This ridge lies along the outcrop of a debris band which varies considerably in thickness along its strike and dips up-glacier at $60^{\circ}$. The ridge is $\mathrm{I} \cdot 5 \mathrm{~m}$. high and $4.5 \mathrm{~m}$. in length, the sediment mantle consists of fine- to coarsegrained gravelly sand with subordinate silt, having a thickness of $0.8 \mathrm{~m}$. on the summit and overlying an ice core whose flanks slope at $35^{\circ}$. The sediments on the down-glacier flank of the ridge have planar bedding with a dip of $30-35^{\circ}$ throughout their whole thickness. The upglacier flank of the ice core is convex, sloping at $60^{\circ}$ at the foot and decreasing to $35^{\circ}$ higher up. The sediments on this flank consist of: a lower bed (" $x$ " in Fig. Iob), which was originally
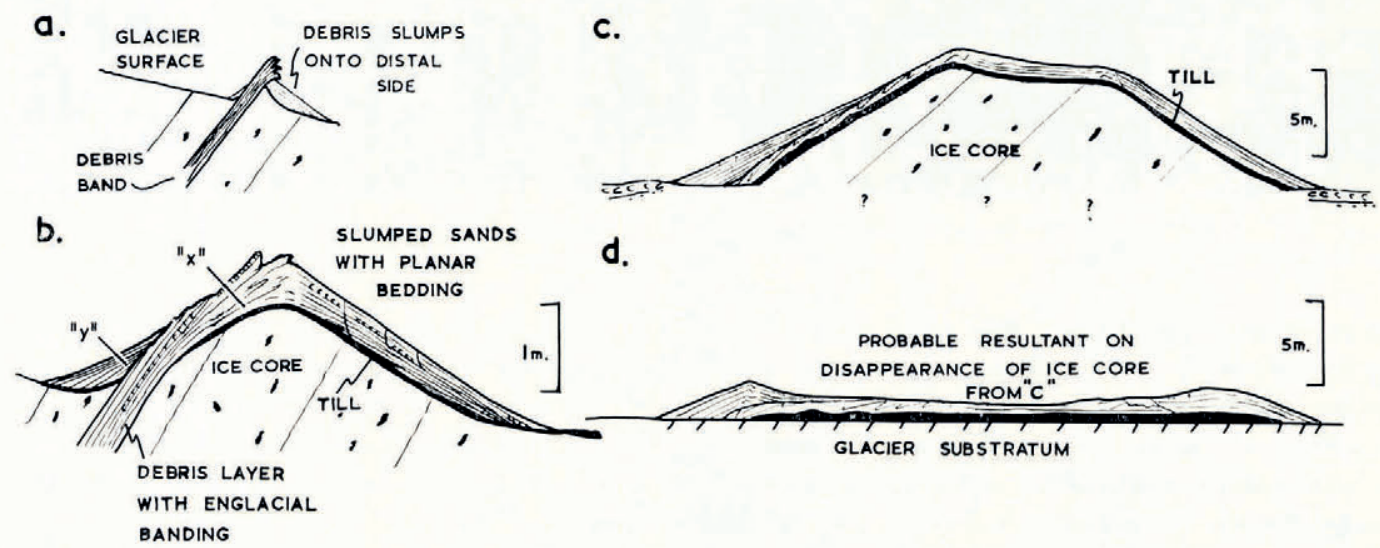

d.

Fig. Io. $a-d$. Cross-ssctions illustrating the development of a ridge from a medium-angle debris band. The ridge " $b$ " is located at $Q$ in Figure Ic, and " $c$ " at $R$ in Figure Ic. Ridge " $d$ " is a hypothetical reconstruction of " $c$ " with the ice core removed. Horizontal and vertical scales are the same 


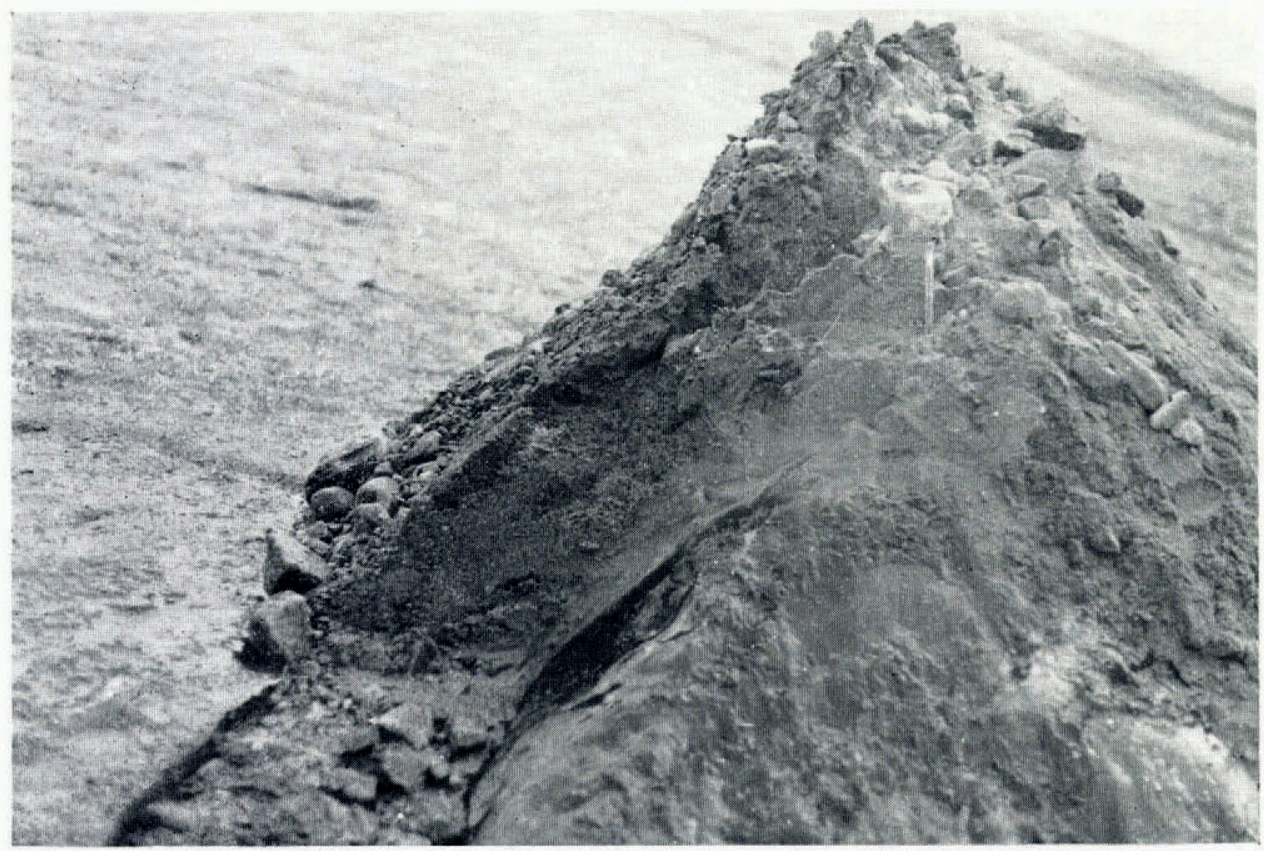

Fig. II. Ridge developed from a medium-angle debris band (cropping out on the left) with part of the sediment mantle removed to reveal the ice core. The boulders on the ridge have slipped down the ice slope to the left. The scale is $18 \mathrm{~cm}$. long

englacial and has retained its englacial structure (this bed is folded into a series of tight isoclinal folds whose axial planes are parallel to the surface of the adjacent ice core); and an upper bed ("y" in Fig. I ob) of planar bedded sands dipping at $35^{\circ}$ and overlying bed " $\mathrm{x}$ " unconformably. The sediments of both the up-glacier and down-glacier slopes are underlain by a thin and variable (up to $15 \mathrm{~cm}$.) till layer which rests directly on the ice core. The upper bedded layer ("y") on the up-glacier flank is derived by slumping from the lower layer ("x"). When the material of this lower layer first emerges from the ice it is frozen and thus able to support itself at a high angle, but as it thaws out material falls from it to form an upper layer which dips at the angle of rest.

Figure I oc shows a ridge (Fig. Ic; R) which probably represents the next stage of development. It is one of a group of flat-topped forms, which lie beyond the glacier front and appear to rest on outwash gravels, the flanks slope at $25^{\circ}$ and the ice core has a flat top. This ridge appears to have been derived from a medium-angle debris band as the structures in the sediment mantle are similar to those of the ridge shown in Figure rob. Thicknesses of up to $30 \mathrm{~cm}$. of till, derived from the wasting ice core, occur between the ice core and the bedded mantle.

Isolated ridges such as those described above are rare, for as ridges derived from debris bands grow in size they tend to merge and ridge complexes are built up. A good section through one of these ridge complexes, partly exposed by melt-water erosion, is shown in Figure 12a. Five major debris bands have contributed to the formation of this complex, three of which are composed of sand and gravel debris and give rise to prominent ridges, whilst two have extruded mainly silty debris which has flowed freely over the surface of the ridge complex. Kettle-holes are developed in several places along the lines of the silt-rich bands. The ice core of the westernmost ridge contains a high proportion of unsorted debris, and as a result the 


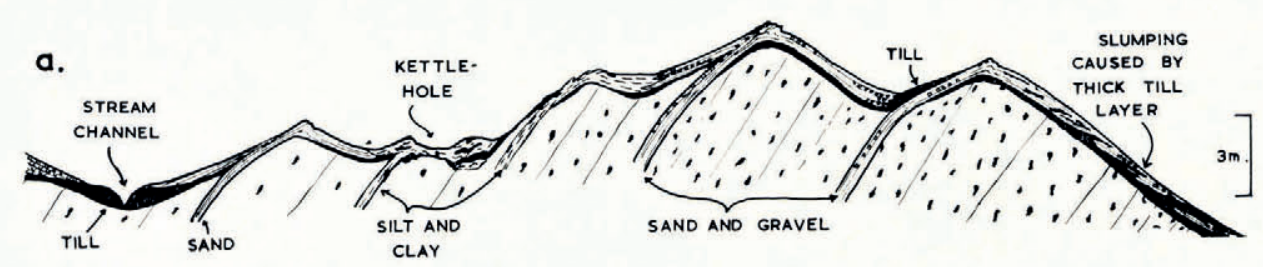

b.

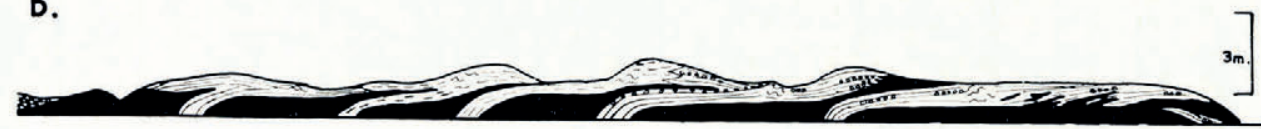

Fig. I2. a. Section through a ridge complex ( $S$ in Figure IC) developed from a series of medium-angle debris bands. This section was exposed in the side of a stream channel. $b$. Probable structure on melting of the underlying ice. Horizontal and vertical scales are the same

sediment mantle is a mixed one of bedded sand with lenses and streaks of slumped till. There are also occasional patches of bare ice on the flanks of this ridge and much wet till with streaks of sand (often showing folded slump structures) occurs around the base. Large-scale crossbedding is developed on the down-glacier side of this outer ridge.

\section{Discussion}

The main difference between the ridges derived from medium-angle debris bands and those derived from high-angle bands is that the sediment tends to form a uniformly thick mantle over the ice cores of the former rather than building up preferentially on the summit. Thus, if it is again assumed that final melting of the ice core does not produce any great rearrangement of the overlying sediment, the resultant form will have a low relief. A flat-topped form (Fig. IOc) is likely to produce a table-like form (Fig. Iod) on melting of the ice core.

Ice-cored ridge complexes derived from medium-angle debris bands are likely to produce a low-relief hummocky topography with a complex internal structure. Figure $12 \mathrm{~b}$ is an approximation of the complex structure which might result on the melting of the ice core of the ridge complex in Figure r $2 \mathrm{a}$.

\section{Ridges Built up at the Steep Glacier Front}

Although the ridges described above lie parallel to the ice front, they do not delimit it. But south of the stagnant areas, at the foot of the steep (active) glacier front, an end moraine has built up. This is $5.5 \mathrm{~m}$. high and is composed of debris falling from the ice wall above. Some of this debris is sorted material derived from low-angle $\left(<30^{\circ}\right)$ debris bands and some is unsorted debris derived from the basal part of the glacier. The resultant ridge sediments are thus composed of poorly sorted material (from clay to boulders $2.4 \mathrm{~m}$. in diameter) and they show only a crude stratification. 45 to $90 \mathrm{~m}$. beyond the glacier front lies a similar ridge (Fig. Ic; G-H), which is surrounded by outwash gravels. On an aerial photograph taken in 1936 this ridge marked the glacier front.

\section{Correlation of Ridges in the Outer Part of the Old Hummocky Moraine with Actively Forming Ridges}

The series of ridges derived from high- and medium-angle debris bands shows an evolution from clearly supraglacial forms with acute ice cores to ridges in the inner part of the old hummocky moraine which have only small ice cores. There is, however, a sharp dividing line between the latter and those in which an ice core is either absent or too deep to be detected. 
This is the line of a deeply cut undulating channel (Fig. Ic; I-J). Beyond this line there is a belt of hummocky moraine (the easternmost part of which is shown in Figure Ic), similar in form to the hummocky moraine areas of Pleistocene age. It trends roughly east-west and was probably parallel to a former glacier front. The component ridges are elongated and mutually parallel, slopes are generally gentler than those in the ridges nearer the glacier margin and individual ridges cover a greater area. This belt of hummocky moraine is cut by a series of channels, often with undulating bed profiles, which are either parallel or transverse to the long axes of the moraine ridges, resulting in a reticulate pattern.

Several topographic elements can be identified in this old hummocky moraine:

i. Acute ridges composed of arch-bedded sands and silts with flanks sloping at angles up to $30^{\circ}$.

ii. Table-like forms, often with a slight summit depression, which form part of a relatively low-relief moraine. They are composed of bedded sands, silts and gravels, which lie horizontally on the summit and dip up to $25^{\circ}$ on the flanks.

iii. Kettle-holes, often with raised rims and sides which consist of silt, clay or sandy till. Some kettle-holes are developed in outwash gravels and the raised rims of many are breached.

Several auger holes were put down in the outer part of the old hummocky moraine to depths ranging from $\mathrm{I} \cdot 2$ to $3.6 \mathrm{~m}$., proving mostly sand and silt with a little gravel. Ice was detected at one locality only, $I \cdot 2 \mathrm{~m}$. below the bottom of a kettle-hole. The form and structure of the ridges which make up this old hummocky moraine (Fig. I3) suggest that they were formed supraglacially from debris bands and that the ice cores have either disappeared or are very small. The table-like forms and the low-relief hummocky moraine are probably derived from medium-angle debris bands, whilst the acute ridges are derived from high-angle debris bands, but raised-rim kettle-holes could be derived from either.

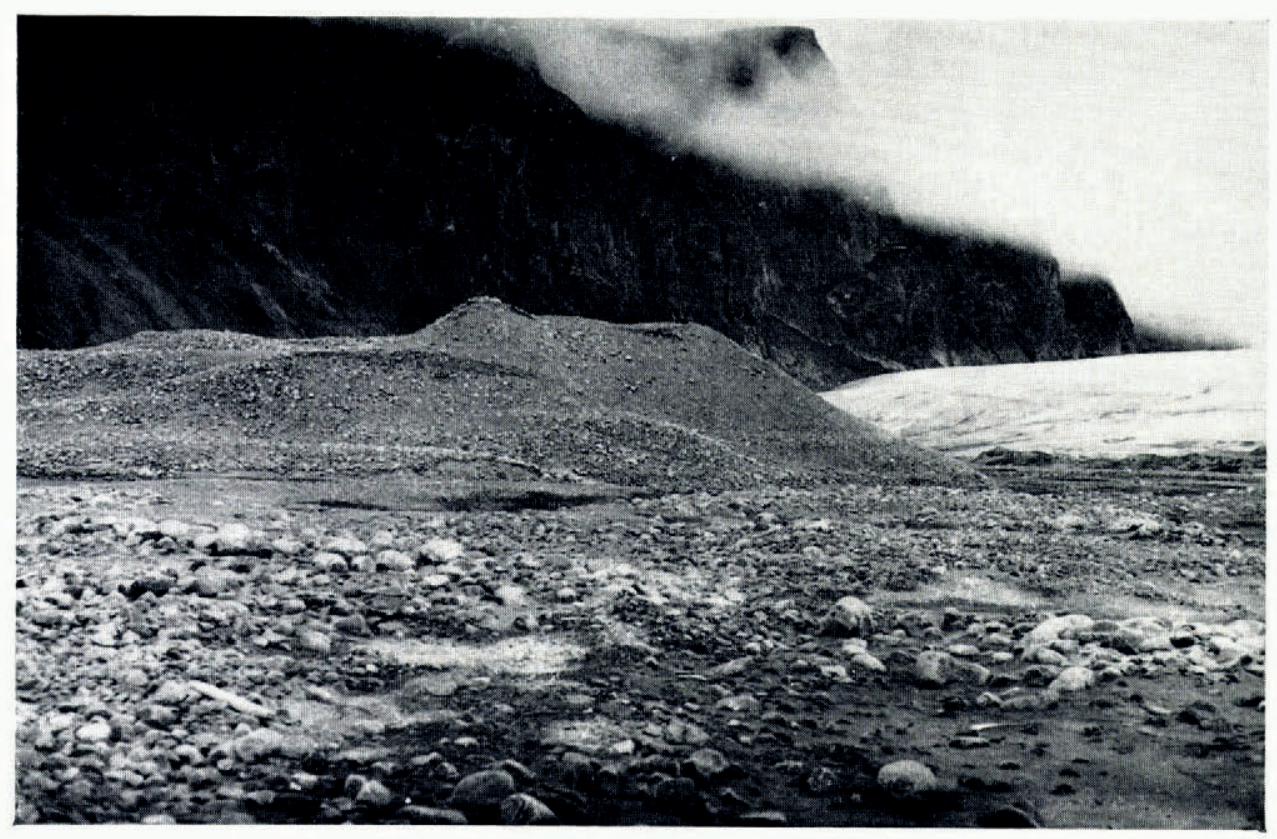

Fig. I3. Part of the old hummocky moraine 
Considering the whole length of this old hummocky moraine (Fig. I3), there is a tendency for the outer part to be of low relief and to include table-like forms, whilst acute ridges occur in the inner part. These two zones probably represent the former positions of medium- and high-angle debris bands, respectively. This zonation could be explained if the outer, probably stagnant, part of the glacier had a debris cover built up from medium-angle debris bands, which would thus be a considerable resistance to the flow of the active ice and might cause the development of high-angle structures on its up-glacier side.

Although upstanding ice cores as such were not detected beneath the mounds making up the outer part of the old hummocky moraine lying beyond the channel I-J (Fig. Ic), it was impossible to determine whether a dead glacier-ice surface exists deep below these morainic deposits. The fact that part of the stagnant glacier margin lies on a level with or below the level of these old morainic deposits (and there is evidence that this stagnant ice is still quite thick) indicates that much of the present extra-glacial outwash is probably underlain by glacier ice as implied in Figure Id. If this is so, and this buried glacier ice is overlain by variable thicknesses of outwash sediment as one would expect, the present flat outwash sheets could develop a hummocky kettled surface when the buried ice disappears; indeed, braided outwash sediments which lie beyond the influence of present-day outwash streams have developed kettle-holes and a hummocky surface.

There are thus two types of hummocky deposit which could develop on the margin of Sørbreen on final melting of the underlying ice: first, ridges and kettle-holes derived directly from debris dykes on the glacier surface, and secondly, hummocks developed from outwash and flowed till, etc., which overlie an irregular surface of dead ice.

Another factor which seems likely to complicate the formation of a hummocky moraine at the stagnant margin of Sørbreen is the existence of a large number of englacial streams. Many of these streams have laid down considerable deposits in their channels, and some of them are now emerging supraglacially (e.g. eskers $\mathrm{K}-\mathrm{L}$ and $\mathrm{M}-\mathrm{N}$ in Figure Ic). Thus, a considerable amount of englacial and subglacial fluvial material lies beneath some of the supraglacial moraine forms and outwash deposits, and it is probable that when the latter are finally deposited on the glacier substratum their surface form will be considerably modified by superimposition on a pattern of subglacial and englacial fluvial deposits. Indeed the strict parallelism which typifies many of the actively forming ridges on the glacier margin appears to have broken down to a certain extent in the outer part of the old hummocky moraine and, whilst much of this may be due to the disappearance of ice cores, it is likely that part is due to the superimposition of supraglacial forms on englacial and subglacial fluvial deposits.

\section{Ablation of Ice Cores}

In early August, when these measurements were made, the ice core of the ridge shown in Figure $4 \mathrm{c}$ was melting under a thickness of $2.5 \mathrm{~m}$. of sand and gravel and up to $30 \mathrm{~cm}$. of wet till, the air temperature at the time being $7^{\circ} \mathrm{C}$. Interpolating from data for Longyearbyen, Vestspitsbergen, it is probable that average temperatures at Sørbreen for the months of June, July and August are above freezing, with average temperatures for September at about $0^{\circ} \mathrm{C}$. Thus, on warm days in August melting goes on under at least $2.75 \mathrm{~m}$. of till (observed at the base of a horizontal till sheet on ice). It is likely therefore that during the other summer months there is active ablation of many ice cores, although it was not possible to determine the maximum depth of cover which would allow ablation. There is also evidence from the ice cores that were examined that there is a net loss of ice during the year. In all these cases there is a sharp contact between the ice cores and the overlying sediment, there being no incorporation of sediment within the ice as would occur if there had been net accretion of ice during the year. Thus, as an exact balance with neither net accretion nor net wastage is extremely unlikely in all these cases, it would appear that the ice cores of moraine ridges around the 
margin of Sørbreen are slowly diminishing. It could even be that snow cover during the winter months hinders freezing, a phenomenon which could produce a very complex movement of the $0^{\circ} \mathrm{C}$. isotherm.

Østrem (1965), working in Norway, found that in an average air temperature somewhat below $10^{\circ} \mathrm{C}$. the $0^{\circ} \mathrm{C}$. isotherm penetrated to $2.5 \mathrm{~m}$. in till overlying an ice core. There is a possibility that similar or greater depths of thawing are attained in till on Sørbreen with lower air temperatures, as there are $24 \mathrm{hr}$. of daylight in summer. Also, the depth of thawing in sand and gravel is likely to be greater than for till because of the penetration of warm air, rain water and melt water through the pore spaces of the sediment, resulting in greater melting of the ice core. It would be interesting to determine the thicknesses of sand and gravel required to inhibit ablation of underlying ice, for if part of the outwash plain of Sørbreen is underlain by dead glacier ice, much of this is probably deep enough to be safe from ablation under present conditions, though the hummocky kettled outwash indicates that some buried ice is actively ablating.

The possibility of the existence of ice cores for long periods of time after deglaciation is an important consideration in dealing with areas of both present-day and ancient glaciation, and it is likely that such ice cores could survive short interstadial periods.

\section{IMPLICATIONS OF THIS WORK}

I. The moraine ridges derived from debris bands at the margin of Sørbreen bear a close similarity to two groups of features which have been described from areas of Pleistocene glaciation:

a. "Controlled disintegration features". These were defined by Gravenor and Kupsch (1959) as reflecting structures of the originally active ice and they mainly consist of linear ridges aligned parallel to former ice fronts. They include such well-known features as "washboard ridges" and are generally explained by one of three hypotheses: the ridges are pressed up subglacially into basal crevasses (Hoppe, i 952) or shear planes (Elson, 1957); they are pushed up frontally by periodic re-advance of the glacier (Gwynne, I942); they are formed by the accumulation of material in crevasses in the glacier surface (Tanner, I9 5 ; Lundqvist, I937).

It is now possible to envisage another mode of origin for many "controlled disintegration features", i.e. they are derived from debris bands which crop out on the glacier surface and have survived melting of the underlying ice. Complex series of "controlled" ridges could then be derived from closely packed debris bands, and single, widely spaced ridges could be derived from widely spaced debris bands. The composition of the ridges would depend on the composition of the debris bands from which they are derived, and they might vary from till to silt, sand and gravel.

b. Bedded ridges and mounds which are generally assumed to be water-deposited and are classified as eskers and kames. Certain of the bedded moraine ridges of Sørbreen have many of the characteristics of eskers; they are arch-bedded, beaded and have a sinuous course, whilst many flat-topped mounds (e.g. some of those derived from medium-angle debris bands) have the form of kames, and the moraine complexes have the form of kame-and-kettle moraine. This is a striking example of the way in which forms of very different origin may have a considerable similarity, although it is possible to differentiate between them on the basis of sedimentary structures. It is not unlikely that a Pleistocene ice sheet, moving over a bed of poorly consolidated sands, would have produced bedded moraines of the type developed on Sørbreen, and a close examination would be required before these could be differentiated from fluvioglacial land forms. Some supposedly fluvioglacial ridges, such as the Aufpressings-Oser of Denmark (Madsen, 
I900; Milthers, I942) which have a till core overlain by steeply dipping beds of sand and gravel, and a vertical dyke along the middle of the ridge are so like the bedded moraine ridges derived from high-angle debris bands on Sørbreen that it is tempting to doubt their fluvial origin.

2. Much of the sediment deposited at the margin of Sørbreen is underlain by glacier ice. Many other glaciers in Vestspitsbergen and Nordaustlandet also have broad areas of ice-cored moraine and show evidence that part of the outwash plain is underlain by ice.

Ice-cored bedded deposits with a hummocky surface form, or concentric series of ice-cored bedded ridges, have previously been taken to be push moraines (Stauchmoränen) originating by the pushing up of fluvial or marine sediments into ridges by re-advance pulses of the glacier during retreat. Some of this bedded hummocky terrain is due to the melting of ice beneath outwash deposits, but many of the so-called push moraines appear to be derived from debris bands and are not the result of pushing up of fluvial and marine sediments by small readvances.

3. The glaciers of Vestspitsbergen and Nordaustlandet, as opposed to those of Greenland and many other Arctic and Antarctic regions, traverse an area of relatively soft sedimentary rocks which often have a thick mantle of unconsolidated deposits. The broad ablation area encourages the development of high-angle structures which emplace this easily eroded debris in a supraglacial position, giving rise to supraglacial hummocky and flat-lying moraine. Englacial fluvial deposits are also common in Vestspitsbergen glaciers (Szupryczyński, I965) and many englacial streams come to the surface in the frontal areas and deposit broad areas of outwash sands and gravels on the ice, thus making it impossible to determine the exact glacier margin.

This is a situation which is probably very similar to that of many of the Pleistocene glaciers of north-western Europe. If this is the case, one would expect the stagnant frontal areas of these glaciers to have had a thick cover of supraglacial moraine and fluvial sediments in addition to extensive subglacial and englacial fluvial deposits. Such a model could explain many of the kame-and-kettle moraine of areas of Pleistocene glaciation. The last stages of stagnation would be marked by active deposition over buried ice, itself full of fluvial sediment and abundant debris, which on final melting (taking perhaps thousands of years) would give rise to a complex hummocky kettle moraine. This would explain several common features of kame-and-kettle moraines:

a. Hummocks of bedded sands whose sedimentary structures indicate an open environment such as one of braided stream channels.

b. Oversteepened beds, normal faulting and other collapse structures.

c. The common occurrence of a till which coats the surface of hummocks.

d. The occurrence of channels with an undulating long profile.

e. Kettle-holes containing organic deposits which began to form long after regional deglaciation.

4. The complex sequences of deposits derived from adjacent debris bands and the interdigitation of till and silt with fluvioglacial deposits at the glacier margin (Fig. Ic) are of considerable interest. Pleistocene sequences of this type have often been interpreted in terms of several phases of glacier advance and retreat on no more evidence than such alternations of till and sand and gravel. For instance, the deposits shown in Figure id (section at locality D) might well have been interpreted as representing the successive advance, retreat and readvance of a glacier. This is obviously not so in the case quoted above, and it is therefore suggested that other criteria, apart from mere lithological variation, should be used to interpret Pleistocene glacial sequences. 


\section{Acknowledgements}

These observations were made while the writer was a member of the $9_{96}$ Cambridge Spitsbergen Expedition. He wishes to thank the Director, W. B. Harland, the Leader, R. H. Wallis, and other members of the expedition for their considerable assistance, and Professor F. W. Cope and Professor T. G. Miller for their encouragement during preparation. Dr. R. J. Adie and Dr. G. R. Coope read the manuscript and made many valuable suggestions. Expenses were defrayed by a generous grant from the University of Keele, England.

MS. received + January 1967

\section{REFERENCES}

Bagnold. R. A. 1954. Experiments on a gravity-free dispersion of large solid spheres in a Newtonian fuid under shear. Proceedings of the Royal Societv. Ser. A, Vol. 225, No. 1160, p. 49-63.

Bishop, B. C. I957. Shear moraines in the Thule area, northwest Greenland. U.S. Snow, Ice and Permafrost Reiearch Establishment. Research Report i 7.

Eison, J. A. 1957. Origin of washboard moraines. Bulletin of the Geological Society of America, Vol. 68, No, 12, p. I $72 \mathrm{I}$. [Äbstract.]

Ciravenor, C. P., and Kupsch, W. O. I959. Ice-disintegration features in western Canada. Fournal of (ieolngy. Vol. 67, No. I, p. $48-64$.

Gripp. K. 1929. Glaciologische und geologische Ergebnisse der Hamburgischen Spitzbergen-Expedition 1927. Vaturwissenschafllicher Verein in Hamburg. Abhandlungen aus dem Gebiet der Naturwissenschaften, Bd. 22, $\mathrm{H1} .2-4$. p. $14^{6-2} 49$.

Giwynne. C. S. 1942. Swell and swale pattern of the Mankato lobe of the Wisconsin drift pluin in Iowa. Joumal of Geolog)' Vol. 50. No. 2. p. 200-08.

Harland, W. B., and Masson-Smith. D. 1962. Cambridge survey of central Vestspitsbergen. Gegraphical Joimal. Vol. i 28 . Pt. I. p. 58-7o.

Hoppe. G. ${ }_{1952}$. Hummocky moraine regions with special reference to the interior of Norrbotten. Geografiska Annaler, Arg. 34, Ht. I-2. p. I-72.

Koch. J. P.. and Wegener, A. 19 7. Die glaciologischen Beobachtungen der Danmark-Expedition. Meddelelser om Gronland. Bd. $46 . \mathrm{Nr}, 1$.

Lamplugh, G. W. I9ı. On the shelly moraine of the Sefström glacier and other Spitsbergen phenomena illustrative of British glacial conditions. Proceedings of the Forkshire Geological Society. Vol. I 7. No. 3. p. 216 4 I.

L.undqvist, G. 1937. Sjösediment frăn Rogenomrădet i Härjedalen. Sueriges Geologiska Undersj̈king. Arhandlingar och Lppsatser. Ser. C. No. 408. Arsbok 3 I. No. 4. p. I-90.

Madsen, Y: 1goo. Kortbladet Bogense. Danmarks Geologiska Interspgelse. I Rakke, No. 7. Milthers, K. 1942. Ledeblokke og Landskabsformer i Danmark. Danmarki Geologiska Cntersogelse, II Rakkt.
Jo. 60.

Ostrem. G. 1959. Ice melting under a thin layer of moraine and the existence of ice cores in moraine ridges. Creogratiska Amaler. Vol. 4 i. No. 4. p. 228-3o.

Ostrem. (i. 1965. Problems of dating ice-cored moraines. Geografiska Annaler. Vol. 47A. No. 1. p. 1. 38.

Schott. C. 1934. Yur Formenstellung der Fisrandlagen Norddeutschlands. Zeitschrift für Gletscherkinde, Bel. 2. 1. Ht. $1-3 \cdot$ p. $54-98$.

Souchez. R. A. Ig66. The origin of morainic deposits and the characteristics of glacial erosion in the western Sor-Rondane. Antarctica. Foumal of Glaciolog). Vol. 6, No. 44. p. 249-54.

Swinzow. G. K. 1962. Investigation of shear zones in the ice sheet margin. Thule arca. Greenland. Foumal of (ilaciologr. Vol. 4. No. 32. p. $215-29$.

Szupryczyński. J. 1965 . Eskers and kames in the Spitsbergen area. Geographia Polonica, [Vol.] 6, p. [27 to.

Fanner. I'. 1915. Siudier öfver Kvartärsystemet i Fennoskandias nordliga delar. III. Om landisens rörelser och afsmältuning i finská Lappland och angränsande trakter. Bullolin de la Commission Géologique de lïnlande. Xo. $3^{8}$ : Fenmia. 36 . No. I.

[Nard. WI. H.] 1953. Glacier bands: conference on teminology. Fournal of Glaciology. Vol. 2, No. 13. p. 220932.

Viecrman, J. 196r. Nechanism for the formation of inner moraines found near the edge of colrl ice caps and ice sheets. Jownal of Glaciology. Vol. 3. No. 30. p. 965-78.

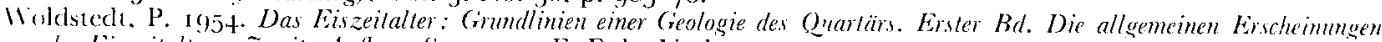
de Eis zeilalier. Eiveite Auflage. Sututgart. F. Enke Verlag. 